\title{
Thermodynamic Analysis of the Fe-Al-C Ternary System by Incorporating ab initio Energetic Calculations into the CALPHAD Approach
}

\author{
Hiroshi OHTANI, ${ }^{1,3)}$ Maki YAMANO ${ }^{2)}$ and Mitsuhiro HASEBE ${ }^{1,3)}$ \\ 1) Department of Materials Science and Engineering, Kyushu Institute of Technology, Kitakyushu $804-8550$ Japan. \\ 2) Graduate School, Kyushu Institute of Technology, Kitakyushu 804-8550 Japan. \\ 3) CREST, Japan Science and Technology Agency.
}

(Received on May 24, 2004; accepted in final form on July 14, 2004)

\begin{abstract}
A thermodynamic analysis of the Fe-C-Al ternary system has been carried out covering a wide range of temperatures and composition. Special care was taken to the expression of the free energy for the ternary Perovskite carbide phase, $\mathrm{Fe}_{3} \mathrm{AIC}(\kappa)$, by considering the crystallographic similarity between the $\kappa$ phase and the $\mathrm{L} 1_{2}$ structure. The free energy was calculated using the $(\mathrm{Fe}, \mathrm{Al})_{3}(\mathrm{Fe}, \mathrm{Al})_{1}(\mathrm{C}, \mathrm{Va})_{1}$ sublattice model, and the $\kappa$ and $L 1_{2}$ structures were treated as a continuous solution. Because of the lack of experimental information available, the thermodynamic properties of the E2 1 structure were evaluated using the Full Potential Linearized Augmented Plane Wave (FLAPW) method.

The ab initio energetic calculations show that the stable $\mathrm{E} 2{ }_{1}$ structure of the $\kappa$ phase is highly preferred compared with the metastable $\mathrm{Fe}_{3} \mathrm{Al}-\mathrm{L} 1_{2}$ structure. Contour plots of the charge density for the $\kappa$ phase indicate that the bonding between the Fe and $\mathrm{C}$ atoms forms in the $\mathrm{Fe}_{3} \mathrm{AIC}-\mathrm{E} 2_{1}$ structure, and that this interaction between the atoms enhances the energetic stability of the $\kappa$ phase.

According to our phase diagram calculations, the $\kappa$ phase is in equilibrium with the fcc Fe, B2-type intermetallic compound, as well as the graphite phase. This finding is in good agreement with previous experimental results.
\end{abstract}

KEY WORDS: phase diagram; thermodynamic analysis; ab initio energetic calculations; ternary carbide.

\section{Introduction}

Phase diagrams offer indispensable information for understanding the thermodynamic properties of steels. The construction of phase diagrams, based on experimental and thermodynamic data, is generally referred to as the Calculation of Phase Diagrams (CALPHAD) approach. ${ }^{1)}$ The use of this method enables an accurate understanding of the properties of a material that originate from its macroscopic characteristics. However, one shortcoming of this approach is that it is difficult to obtain information on metastable equilibria, or on unknown phases, since the thermodynamic parameters from this method can only be evaluated from experimental data. Such a serious problem, which is intrinsic to the CALPHAD approach, may be circumvented by employing a first principle energetic calculation method, such as the Full Potential Linearized Augmented Plane Wave (FLAPW) method. ${ }^{2}$ Our group has attempted to combine $a b$ initio energetic calculations with CALPHAD techniques to predict metastable or unstable phase equilibria in materials. Table $\mathbf{1}^{3)}$ shows a comparison of the calculated formation energies for some binary ordered phases with experimental data. The alloy systems shown in Table 1 have known thermodynamic properties, and the calculated values and experimental data show reasonable consistency in these metallic compounds. Case studies of the applicability of this new method to ferrous materials are few. However, the close agreement seen in the Table 1 has encouraged us to apply the new procedure to calculate the phase diagram of the $\mathrm{Fe}-\mathrm{Al}-\mathrm{C}$ ternary system.

The Perovskite carbide in this ternary system, $\mathrm{Fe}_{3} \mathrm{AlC}$ $(\kappa)$, is an fcc-based ordered phase with an E2 ${ }_{1}$-type structure, in which a carbon atom occupies the octahedral interstices formed by six Fe atoms in an fcc ordered arrangement, with the remaining $\mathrm{Fe}$ and $\mathrm{Al}$ atoms in an $\mathrm{L}_{2}$-type structure. The application of this material as a heat resistant

Table 1. Comparison of the estimated formation enthalpies for some ordered structures with the appropriate evaluated data.

\begin{tabular}{|c|c|c|c|c|}
\hline \multirow{2}{*}{$\begin{array}{c}\text { Alloy } \\
\text { Systems }\end{array}$} & Structures & Temperature & Experimental Values & Calculated Values \\
\cline { 3 - 5 } & & $\left({ }^{\circ} \mathrm{C}\right)$ & $(\mathrm{kJ} / \mathrm{mol})$ & $(\mathrm{kJ} / \mathrm{mol})$ \\
\hline \multirow{2}{*}{$\mathrm{Al}-\mathrm{Ni}$} & $\mathrm{B} 2$ & 25 & -71.7 & -69.5 \\
\cline { 2 - 5 } & $\mathrm{L}_{2}$ & 25 & -41.0 & -40.5 \\
\hline \multirow{2}{*}{$\mathrm{Al}-\mathrm{Ti}$} & $\mathrm{L}_{0}$ & 25 & -39.8 & -39.6 \\
\cline { 2 - 5 } & $\mathrm{D0}_{19}\left(\mathrm{Ti}_{3} \mathrm{Al}\right)$ & 25 & -27.5 & -27.3 \\
\hline \multirow{2}{*}{$\mathrm{Be}-\mathrm{Cu}$} & $\mathrm{B} 2$ & 25 & -21.4 & -19.0 \\
\hline $\mathrm{Fe}-\mathrm{Pd}$ & $\mathrm{B} 2$ & 25 & -15.6 & -13.2 \\
\hline \multirow{2}{*}{$\mathrm{Fe}-\mathrm{Ti}$} & $\mathrm{B} 2$ & 25 & -51.6 & -46.5 \\
\hline \multirow{2}{*}{$\mathrm{Ni}-\mathrm{Ti}$} & $\mathrm{B} 2$ & 726 & -34.2 & -34.1 \\
\cline { 2 - 5 } & $\mathrm{D}_{24}\left(\mathrm{Ni}_{3} \mathrm{Ti}\right)$ & 554 & -54.0 & -51.4 \\
\hline \multirow{2}{*}{$\mathrm{Al}-\mathrm{Li}$} & $\mathrm{B} 32$ & 25 & -22.8 & -23.1 \\
\hline
\end{tabular}


alloy from the formation of a coherent fine microstructure consisting of an fcc solid solution and the $\kappa$ phase is attracting great attention. ${ }^{4)}$ Regardless of such a promising potential for this new material, little information on the thermodynamic properties of this carbide phase is known. Thus, we have attempted to calculate the formation energy of $\mathrm{Fe}_{3} \mathrm{AlC}$ using a first principle band energetic calculation method. The objective of the present study was to introduce estimated values into a CALPHAD-type thermodynamic analysis, and to clarify the full phase equilibria of the $\mathrm{Fe}-\mathrm{Al}-\mathrm{C}$ ternary system.

\section{Computational Procedures}

The formation energy of the phase was calculated using the FLAPW method. A brief outline of the computational method and a description of the Gibbs free energy for each phase adopted in the thermodynamic analysis will be presented.

\subsection{Ab initio Energetic Calculations}

The FLAPW method, as embodied in the WIEN2k ${ }^{5}$ ) software package, is one of the most accurate schemes for electronic calculations and allows for very precise calculations of the total energies in a solid, and was employed in our energetic calculations. The FLAPW method uses a scheme for solving many-electron problems based on the local spin density approximation (LSDA) technique. In this framework, a unit cell is divided into two regions: non-overlapping atomic spheres and an interstitial region. Inside the atomic spheres, the wave functions of the valence states are expanded using a linear combination of radial functions and spherical harmonics, while a plane wave expansion is used in the interstitial region. The LSDA technique includes an approximation for both the exchange and correlation energies, and it has been recently enhanced by the addition of electron density gradient terms to the exchange-correlation energy. This has led to a generalized gradient approximation (GGA), as suggested by Perdew et al., ${ }^{6}$ and we used this improved method rather than the LSDA approach.

In our calculations, we assumed muffin-tin radii of 2.0 au $(0.106 \mathrm{~nm})$ for $\mathrm{Fe}$ and $\mathrm{Al}$, and $1.4 \mathrm{au}(0.742 \mathrm{~nm})$ for $\mathrm{C}$, and the value of $\mathrm{RK}_{\max }$ was fixed at 6.26 for $\mathrm{C}$ atom, which almost corresponds to the cut-off energy of $20 \mathrm{Ry}(270 \mathrm{eV})$ used throughout this study. Inside the muffin-tin spheres, the wave function was expanded using spherical harmonics with values of $l_{\max }=10$ for the potential and charge density representations, while non-spherical components of the density and potentials were included up to values of $l_{\max }=6$. Spin-polarized electronic structure calculations were carried out for the $\kappa$ phase, and calculations of the total energy as a function of the cell volume were performed around the equilibrium cell volumes.

\subsection{Thermodynamic Modelling of the Solution Phases}

\subsubsection{Liquid (L)}

The regular solution approximation was applied to the liquid phase. The molar Gibbs energy, $G_{\mathrm{m}}^{\mathrm{L}}$, was calculated using Eq. (1).

$$
\begin{aligned}
G_{\mathrm{m}}^{\mathrm{L}}= & x_{\mathrm{Al}}^{\mathrm{L}}{ }^{\circ} G_{\mathrm{Al}}^{\mathrm{L}}+x_{\mathrm{C}}^{\mathrm{L} \circ} G_{\mathrm{C}}^{\mathrm{L}}+x_{\mathrm{Fe}}^{\mathrm{L} o} G_{\mathrm{Fe}}^{\mathrm{L}} \\
& +R T\left(x_{\mathrm{Al}}^{\mathrm{L}} \ln x_{\mathrm{Al}}^{\mathrm{L}}+x_{\mathrm{C}}^{\mathrm{L}} \ln x_{\mathrm{C}}^{\mathrm{L}}+x_{\mathrm{Fe}}^{\mathrm{L}} \ln x_{\mathrm{Fe}}^{\mathrm{L}}\right)
\end{aligned}
$$

$$
\begin{aligned}
& +x_{\mathrm{Al}}^{\mathrm{L}} x_{\mathrm{C}}^{\mathrm{L}} L_{\mathrm{Al}, \mathrm{C}}^{\mathrm{L}}+x_{\mathrm{Al}}^{\mathrm{L}} x_{\mathrm{Fe}}^{\mathrm{L}} L_{\mathrm{Al}, \mathrm{Fe}}^{\mathrm{L}}+x_{\mathrm{C}}^{\mathrm{L}} x_{\mathrm{Fe}}^{\mathrm{L}} L_{\mathrm{C}, \mathrm{Fe}}^{\mathrm{L}} \\
& +x_{\mathrm{Al}}^{\mathrm{L}} x_{\mathrm{C}}^{\mathrm{L}} x_{\mathrm{Fe}}^{\mathrm{L}} L_{\mathrm{Al}, \mathrm{C}, \mathrm{Fe}}^{\mathrm{L}} \cdots \cdots \cdots \cdots \cdots \cdots \cdots \cdots \cdots \cdots \cdots
\end{aligned}
$$

where ${ }^{\circ} G_{i}^{\mathrm{L}}$ denotes the Gibbs energy of element $i$ in the liquid state. This quantity is called the lattice stability parameter, and is described by

$$
\begin{aligned}
{ }^{\circ} G_{i}{ }^{\varphi}-{ }^{\circ} H_{i}^{\mathrm{ref}}= & A+B T+C T \ln T+D T^{2}+E T^{3} \\
& +F T^{7}+I T^{-1}+J T^{-9} \ldots \ldots \ldots \ldots \ldots \ldots
\end{aligned}
$$

where ${ }^{\circ} H_{i}^{\text {ref }}$ denotes the enthalpy of the pure element $i$ in its stable state at $T=25^{\circ} \mathrm{C}$. The parameter $L_{i, j}^{\mathrm{L}}$ denotes the interaction energy between $i$ and $j$ in the liquid phase, and has a compositional dependency following the Redlich-Kister polynomial as

$$
L_{i, j}^{\mathrm{L}}={ }^{0} L_{i, j}^{\mathrm{L}}+{ }^{1} L_{i, j}^{\mathrm{L}}\left(x_{i}^{\mathrm{L}}-x_{j}^{\mathrm{L}}\right)+{ }^{2} L_{i, j}^{\mathrm{L}}\left(x_{i}^{\mathrm{L}}-x_{j}^{\mathrm{L}}\right)^{2}+\cdots+{ }^{n} L_{i, j}^{\mathrm{L}}\left(x_{i}^{\mathrm{L}}-x_{j}^{\mathrm{L}}\right)^{n}
$$

where

$$
{ }^{n} L_{i, j}^{\mathrm{L}}=a+b T+c T \ln T+d T^{2}+\cdots .
$$

The term $L_{\mathrm{Al}, \mathrm{C}, \mathrm{Fe}}^{\mathrm{L}}$ is the ternary interaction parameter between elements $\mathrm{Al}, \mathrm{C}$, and $\mathrm{Fe}$, respectively. The composition dependency of the interaction parameters is expressed as follows.

$$
L_{\mathrm{Al}, \mathrm{C}, \mathrm{Fe}}^{\mathrm{L}}=x_{\mathrm{Al}}^{\mathrm{L} 0} L_{\mathrm{Al}, \mathrm{C}, \mathrm{Fe}}^{\mathrm{L}}+x_{\mathrm{C}}^{\mathrm{L} 1} L_{\mathrm{Al}, \mathrm{C}, \mathrm{Fe}}^{\mathrm{L}}+x_{\mathrm{Fe}}^{\mathrm{L}}{ }^{2} L_{\mathrm{Al}, \mathrm{C}, \mathrm{Fe}}^{\mathrm{L}}
$$

Equation (1) was also applied to the Gibbs energy of the $\mathrm{Fe}_{4} \mathrm{Al}_{5}$ phase.

\subsubsection{Fcc Solid Solution $(\gamma)$}

The fcc solid solution, which contains a range of nonstoichiometric alloys, was modelled using a two-sublattice model, ${ }^{7)}$ with a general formula is described by

$$
\left(\mathrm{Fe}_{y_{\mathrm{Fe}}^{(1)}} \mathrm{Al}_{y_{\mathrm{Al}}^{(1)}}\right)_{u^{1}}\left(\mathrm{C}_{y_{\mathrm{C}}^{(2)}} \mathrm{Va}_{y_{\mathrm{Va}}^{(2)}}\right)_{u^{2}}
$$

where $u^{1}$ and $u^{2}$ are the numbers of the sites of the sublattice that are bracketed, and straightforwardly, $u^{1}=u^{2}=1$ for the fcc phase. The quantities $y_{i}^{(1)}$ and $y_{i}^{(2)}$ are the site fractions of elements and in their respective sublattice, and are designated by the numbers 1 and 2 .

The Gibbs energy of the phase is expressed by the following equation.

$$
\begin{aligned}
& G^{\gamma}=y_{\mathrm{Al}}^{(1)} y_{\mathrm{Va}}^{(2)}{ }^{\circ} G_{\mathrm{Al}: \mathrm{Va}}^{\gamma}+y_{\mathrm{Fe}}^{(1)} y_{\mathrm{Va}}^{(2)}{ }^{\circ} G_{\mathrm{Fe}: \mathrm{Va}}^{\gamma} \\
& +y_{\mathrm{Al}}^{(1)} y_{\mathrm{C}}^{(2)}{ }^{\circ} G_{\mathrm{Al}: \mathrm{C}}^{\gamma}+y_{\mathrm{Fe}}^{(1)} y_{\mathrm{C}}^{(2)}{ }^{\circ} G_{\mathrm{Fe}: \mathrm{C}}^{\gamma} \\
& +R T\left\{y_{\mathrm{Al}}^{(1)} \ln y_{\mathrm{Al}}^{(1)}+y_{\mathrm{Fe}}^{(1)} \ln y_{\mathrm{Fe}}^{(1)}+y_{\mathrm{C}}^{(2)} \ln y_{\mathrm{C}}^{(2)}+y_{\mathrm{Va}}^{(2)} \ln y_{\mathrm{Va}}^{(2)}\right\} \\
& +y_{\mathrm{Al}}^{(1)} y_{\mathrm{Fe}}^{(1)} y_{\mathrm{Va}}^{(2)} \sum_{v}{ }^{v} L_{\mathrm{Al}, \mathrm{Fe}: \mathrm{Va}}^{\gamma}\left(y_{\mathrm{Al}}^{(1)}-y_{\mathrm{Fe}}^{(1)}\right)^{v} \\
& +y_{\mathrm{Al}}^{(1)} y_{\mathrm{Fe}}^{(1)} y_{\mathrm{C}}^{(2)} \sum_{v}{ }^{v} L_{\mathrm{Al}, \mathrm{Fe}: \mathrm{C}}^{\gamma}\left(y_{\mathrm{Al}}^{(1)}-y_{\mathrm{Fe}}^{(1)}\right)^{v} \\
& +y_{\mathrm{Al}}^{(1)} y_{\mathrm{C}}^{(2)} y_{\mathrm{Va}}^{(2)} \sum_{v}{ }^{v} L_{\mathrm{Al} \mathrm{C}, \mathrm{Va}}^{\gamma}\left(y_{\mathrm{C}}^{(2)}-y_{\mathrm{Va}}^{(2)}\right)^{v} \\
& +y_{\mathrm{Fe}}^{(1)} y_{\mathrm{C}}^{(2)} y_{\mathrm{Va}}^{(2)} \sum_{v}{ }^{v} L_{\mathrm{Fe}: \mathrm{C}, \mathrm{Va}}^{\gamma}\left(y_{\mathrm{C}}^{(2)}-y_{\mathrm{Va}}^{(2)}\right)^{v}
\end{aligned}
$$

where ${ }^{\circ} G_{i: j}$ denotes the Gibbs energy of a hypothetical compound $i_{u^{1}} j_{u^{2}}$, and terms relative to the same stoichiometry are identical, whatever the occupation of the sublattice. The 
parameter $L_{i, j: k}$ (or $L_{i: j, k}$ ) is the interaction parameter between unlike atoms on the same sublattice.

\subsubsection{Bcc Solid Solution $(\beta)$}

In the thermodynamic modelling of the bcc structure, the three-sublattice model described by $\left(\mathrm{Fe}_{y_{\mathrm{Fe}}^{(1)}} \mathrm{Al}_{y_{\mathrm{Al}}^{(1)}}\right)_{u^{1}}$ $\left(\mathrm{Fe}_{y_{\mathrm{Fe}}^{(2)}} \mathrm{Al}_{y_{\mathrm{Al}}^{(2)}}\right)_{u^{2}}\left(\mathrm{C}_{y_{\mathrm{C}}^{(3)}} \mathrm{Va}_{y_{\mathrm{V}}^{(3)}}\right)_{u^{3}}$ was applied to the $\kappa$ phase to consider the order-disorder transition between the B2 and $\mathrm{A} 2$ structures in the $\mathrm{Fe}-\mathrm{Al}$ system. In the above formula, the first and second sublattices represent the substitution sites occupied by the metallic elements, while the third sublattice represents the interstitial sites in which the carbon atoms and the vacancies are located. The values of the numbers of the sublattice sites for the $\beta$ phase are $u^{1}=u^{2}=0.5$ and $u^{3}=3$. The quantity $y_{i}^{(1)}$ has the same meaning as in Eq. (6). The Gibbs energy of the phase is expressed as follows.

$$
\begin{aligned}
G^{\beta}= & y_{\mathrm{Al}}^{(1)} y_{\mathrm{Al}}^{(2)} y_{\mathrm{C}}^{(3)}{ }^{\circ} G_{\mathrm{Al}: \mathrm{Al}: \mathrm{C}}^{\beta}+y_{\mathrm{Al}}^{(1)} y_{\mathrm{Al}}^{(2)} y_{\mathrm{Va}}^{(3)}{ }^{\circ} G_{\mathrm{Al}: \mathrm{Al}: \mathrm{Va}}^{\beta} \\
& +y_{\mathrm{Al}}^{(1)} y_{\mathrm{Fe}}^{(2)} y_{\mathrm{C}}^{(3) \circ} G_{\mathrm{Al}: \mathrm{Fe}: \mathrm{C}}^{\beta}+y_{\mathrm{Al}}^{(1)} y_{\mathrm{Fe}}^{(2)} y_{\mathrm{Va}}^{(3)}{ }^{\circ} G_{\mathrm{Al}: \mathrm{Fe}: \mathrm{Va}}^{\beta} \\
& +y_{\mathrm{Fe}}^{(1)} y_{\mathrm{Al}}^{(2)} y_{\mathrm{C}}^{(3)}{ }^{\circ} G_{\mathrm{Fe}: \mathrm{Al}: \mathrm{C}}^{\beta}+y_{\mathrm{Fe}}^{(1)} y_{\mathrm{Al}}^{(2)} y_{\mathrm{Va}}^{(3)}{ }^{\circ} G_{\mathrm{Fe}: \mathrm{Al}: \mathrm{Va}}^{\beta} \\
& +y_{\mathrm{Fe}}^{(1)} y_{\mathrm{Fe}}^{(2)} y_{\mathrm{C}}^{(3)}{ }^{\circ} G_{\mathrm{Fe}: \mathrm{Fe} \mathrm{C}}^{\beta}+y_{\mathrm{Fe}}^{(1)} y_{\mathrm{Fe}}^{(2)} y_{\mathrm{Va}}^{(3)}{ }^{\circ} G_{\mathrm{Fe}: \mathrm{Fe}: \mathrm{Va}}^{\beta} \\
& +0.5 R T\left(y_{\mathrm{Al}}^{(1)} \ln y_{\mathrm{Al}}^{(1)}+y_{\mathrm{Fe}}^{(1)} \ln y_{\mathrm{Fe}}^{(1)}\right) \\
& +0.5 R T\left(y_{\mathrm{Al}}^{(2)} \ln y_{\mathrm{Al}}^{(2)}+y_{\mathrm{Fe}}^{(2)} \ln y_{\mathrm{Fe}}^{(2)}\right) \\
& +3 R T\left(y_{\mathrm{C}}^{(3)} \ln y_{\mathrm{C}}^{(3)}+y_{\mathrm{Va}}^{(3)} \ln y_{\mathrm{Va}}^{(3)}\right) \\
& +y_{\mathrm{Al}}^{(1)} y_{\mathrm{Fe}}^{(1)} y_{\mathrm{Al}}^{(2)} y_{\mathrm{C}}^{(3)} L_{\mathrm{Al}, \mathrm{Fe}: \mathrm{Al}: \mathrm{C}}^{\beta}+y_{\mathrm{Al}}^{(1)} y_{\mathrm{Fe}}^{(1)} y_{\mathrm{Al}}^{(2)} y_{\mathrm{Va}}^{(3)} L_{\mathrm{Al}, \mathrm{Fe}: \mathrm{Al}: \mathrm{Va}}^{\beta} \\
& +y_{\mathrm{Al}}^{(1)} y_{\mathrm{Fe}}^{(1)} y_{\mathrm{Fe}}^{(2)} y_{\mathrm{C}}^{(3)} L_{\mathrm{Al}, \mathrm{Fe}: \mathrm{Fe}: \mathrm{C}}+y_{\mathrm{Al}}^{(1)} y_{\mathrm{Fe}}^{(1)} y_{\mathrm{Fe}}^{(2)} y_{\mathrm{Va}}^{(3)} L_{\mathrm{Al}, \mathrm{Fe}: \mathrm{Fe}: \mathrm{Va}} \\
& +y_{\mathrm{Al}}^{(1)} y_{\mathrm{Al}}^{(2)} y_{\mathrm{Fe}}^{(2)} y_{\mathrm{C}}^{(3)} L_{\mathrm{Al}: \mathrm{Al}, \mathrm{Fe}: \mathrm{C}}^{\beta}+y_{\mathrm{Al}}^{(1)} y_{\mathrm{Al}}^{(2)} y_{\mathrm{Fe}}^{(2)} y_{\mathrm{Va}}^{(3)} L_{\mathrm{Al}: \mathrm{Al}, \mathrm{Fe}: \mathrm{Va}}^{\beta} \\
& +y_{\mathrm{Fe}}^{(1)} y_{\mathrm{Al}}^{(2)} y_{\mathrm{Fe}}^{(2)} y_{\mathrm{C}}^{(3)} L_{\mathrm{Fe}: \mathrm{Al}, \mathrm{Fe} \mathrm{C} \mathrm{C}}^{\beta}+y_{\mathrm{Fe}}^{(1)} y_{\mathrm{Al}}^{(2)} y_{\mathrm{Fe}}^{(2)} y_{\mathrm{Va}}^{(3)} L_{\mathrm{Fe}: \mathrm{Al}, \mathrm{Fe}: \mathrm{Va}}^{\beta} \\
& +y_{\mathrm{Al}}^{(1)} y_{\mathrm{Al}}^{(2)} y_{\mathrm{C}}^{(3)} y_{\mathrm{Va}}^{(3)} L_{\mathrm{Al}: \mathrm{Al}: \mathrm{C}, \mathrm{Va}}^{\beta}+y_{\mathrm{Al}}^{(1)} y_{\mathrm{Fe}}^{(2)} y_{\mathrm{C}}^{(3)} y_{\mathrm{Va}}^{(3)} L_{\mathrm{Al}: \mathrm{Fe}: \mathrm{C}, \mathrm{Va}}^{\beta} \\
& +y_{\mathrm{Fe}}^{(1)} y_{\mathrm{Al}}^{(2)} y_{\mathrm{C}}^{(3)} y_{\mathrm{Va}}^{(3)} L_{\mathrm{Fe}: \mathrm{Al}: \mathrm{C}, \mathrm{Va}}^{\beta}+y_{\mathrm{Fe}}^{(1)} y_{\mathrm{Fe}}^{(2)} y_{\mathrm{C}}^{(3)} y_{\mathrm{Va}}^{(3)} L_{\mathrm{Fe}: \mathrm{Fe}: \mathrm{C}, \mathrm{Va}}^{\beta} \cdots
\end{aligned}
$$

where ${ }^{\circ} G_{i: j: k}$ represents the Gibbs energy of a hypothetical compound $i_{u^{1}} j_{u^{2}} k_{u^{3}}$, and terms relative to the same stoichiometry are identical. The parameter $L_{i, j: k: l}$ denotes the interaction energies between unlike atoms on the same sublattice.

\subsubsection{Perovskite-type Carbide $(\kappa)$}

There is only one known ternary phase in the $\mathrm{Fe}-\mathrm{Al}-\mathrm{C}$ system, $\mathrm{Fe}_{3} \mathrm{AlC}$. In this structure, the $\mathrm{Fe}$ and $\mathrm{Al}$ atoms are arranged in an $\mathrm{L1}_{2}$-type superlattice, in which the $\mathrm{C}$ atoms occupy interstitial sites, resulting in an E2 superstructure. Figures 1(a) and 1(b) show schematic diagrams of the $\mathrm{Fe}_{3} \mathrm{Al}-\mathrm{L} 1_{2}$ and $\mathrm{Fe}_{3} \mathrm{AlC}-\mathrm{E} 2_{1}$ structures, respectively. If the $\mathrm{C}$ atom occupies only the body-centred sites, then it is surrounded by six $\mathrm{Fe}$ atoms, and this is preferable from an energetic point of view. Occupation of the other fcc interstitial sites enhances the tetragonality of the $\mathrm{L}_{2}$ crystal structure, yielding a larger strain energy. The only difference between these two structures is the existence of $\mathrm{C}$ atoms in the octahedral interstitial sites. Therefore, the Gibbs free energies of these two ordered structures should be described by the same thermodynamic model. The two-sublattice model denoted by the formula, $\left(\mathrm{Fe}_{y_{\mathrm{Fe}}^{(1)}} \mathrm{Al}_{y_{\mathrm{Al}}^{(1)}}\right)_{3}\left(\mathrm{Fe}_{y_{\mathrm{Fe}}^{(2)}} \mathrm{Al}_{y_{\mathrm{Al}}^{(2)}}\right)$, was

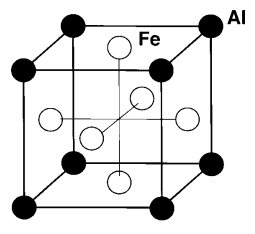

(a) $\mathrm{Fe}_{3} \mathrm{Al}-\mathrm{L} 12$

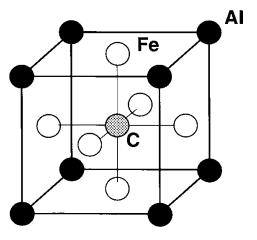

(b) FesAIC-E21

Fig. 1. Crystal structures for: (a) $\mathrm{Fe}_{3} \mathrm{Al}-\mathrm{L} 1_{2}$ and (b) $\mathrm{Fe}_{3} \mathrm{AlC}-\mathrm{E} 2_{1}$.

generally applied to the $\mathrm{L1}_{2}$ structure, and the threesublattice model, $\left(\mathrm{Fe}_{y_{\mathrm{Fe}}^{(1)}} \mathrm{Al}_{y_{\mathrm{Al}}^{(1)}}\right)_{3}\left(\mathrm{Fe}_{y_{\mathrm{Fe}}^{(2)}} \mathrm{Al}_{y_{\mathrm{Al}}^{(2)}}\right)_{1}\left(\mathrm{C}_{y_{\mathrm{C}}^{(3)}} \mathrm{Va}_{y_{\mathrm{Va}}^{(3)}}\right)_{1}$, was applied to the $\kappa$ phase. This model was near identical to that used for the $\beta$ phase in Eq. (8), assuming $u^{1}=3$, $u^{2}=1$, and $u^{3}=1$. The Gibbs free energy for the $\kappa$ phase was calculated using Eq. (9).

$$
\begin{aligned}
G^{\kappa}= & y_{\mathrm{Al}}^{(1)} y_{\mathrm{Al}}^{(2)} y_{\mathrm{C}}^{(3) \circ} G_{\mathrm{Al}: \mathrm{Al}: \mathrm{C}}^{\kappa}+y_{\mathrm{Al}}^{(1)} y_{\mathrm{Al}}^{(2)} y_{\mathrm{Va}}^{(3)}{ }^{\circ} G_{\mathrm{Al}: \mathrm{Al}: \mathrm{Va}}^{\kappa} \\
& +y_{\mathrm{Al}}^{(1)} y_{\mathrm{Fe}}^{(2)} y_{\mathrm{C}}^{(3)}{ }^{\circ} G_{\mathrm{Al}: \mathrm{Fe}: \mathrm{C}}^{\kappa}+y_{\mathrm{Al}}^{(1)} y_{\mathrm{Fe}}^{(2)} y_{\mathrm{Va}}^{(3) \circ} G_{\mathrm{Al}: \mathrm{Fe}: \mathrm{Va}}^{\kappa} \\
& +y_{\mathrm{Fe}}^{(1)} y_{\mathrm{Al}}^{(2)} y_{\mathrm{C}}^{(3)}{ }^{\circ} G_{\mathrm{Fe}: \mathrm{Al}: \mathrm{C}}^{\kappa}+y_{\mathrm{Fe}}^{(1)} y_{\mathrm{Al}}^{(2)} y_{\mathrm{Va}}^{(3)}{ }^{\circ} G_{\mathrm{Fe}: \mathrm{Al}: \mathrm{Va}}^{\kappa} \\
& +y_{\mathrm{Fe}}^{(1)} y_{\mathrm{Fe}}^{(2)} y_{\mathrm{C}}^{(3)}{ }^{\circ} G_{\mathrm{Fe}: \mathrm{Fe}: \mathrm{C}}^{\kappa}+y_{\mathrm{Fe}}^{(1)} y_{\mathrm{Fe}}^{(2)} y_{\mathrm{Va}}^{(3)}{ }^{\circ} G_{\mathrm{Fe}: \mathrm{Fe}: \mathrm{Va}}^{\kappa} \\
& +3 R T\left(y_{\mathrm{Al}}^{(1)} \ln y_{\mathrm{Al}}^{(1)}+y_{\mathrm{Fe}}^{(1)} \ln y_{\mathrm{Fe}}^{(1)}\right)+R T\left(y_{\mathrm{Al}}^{(2)} \ln y_{\mathrm{Al}}^{(2)}+y_{\mathrm{Fe}}^{(2)} \ln y_{\mathrm{Fe}}^{(2)}\right) \\
& +R T\left(y_{\mathrm{C}}^{(3)} \ln y_{\mathrm{C}}^{(3)}+y_{\mathrm{Va}}^{(3)} \ln y_{\mathrm{Va}}^{(3)}\right) \\
& +y_{\mathrm{Al}}^{(1)} y_{\mathrm{Fe}}^{(1)} y_{\mathrm{Al}}^{(2)} y_{\mathrm{C}}^{(3)} L_{\mathrm{Al}, \mathrm{Fe}: \mathrm{Al}: \mathrm{C}}^{\kappa}+y_{\mathrm{Al}}^{(1)} y_{\mathrm{Fe}}^{(1)} y_{\mathrm{Al}}^{(2)} y_{\mathrm{Va}}^{(3)} L_{\mathrm{Al}, \mathrm{Fe}: \mathrm{Al}: \mathrm{Va}}^{\kappa} \\
& +y_{\mathrm{Al}}^{(1)} y_{\mathrm{Fe}}^{(1)} y_{\mathrm{Fe}}^{(2)} y_{\mathrm{C}}^{(3)} L_{\mathrm{Al}, \mathrm{Fe}: \mathrm{Fe}: \mathrm{C}}+y_{\mathrm{Al}}^{(1)} y_{\mathrm{Fe}}^{(1)} y_{\mathrm{Fe}}^{(2)} y_{\mathrm{Va}}^{(3)} L_{\mathrm{Al}, \mathrm{Fe}: \mathrm{Fe}: \mathrm{Va}}^{\kappa} \\
& +y_{\mathrm{Al}}^{(1)} y_{\mathrm{Al}}^{(2)} y_{\mathrm{Fe}}^{(2)} y_{\mathrm{C}}^{(3)} L_{\mathrm{Al}: \mathrm{Al}, \mathrm{Fe}: \mathrm{C}}^{\kappa}+y_{\mathrm{Al}}^{(1)} y_{\mathrm{Al}}^{(2)} y_{\mathrm{Fe}}^{(2)} y_{\mathrm{Va}}^{(3)} L_{\mathrm{Al}: \mathrm{Al}, \mathrm{Fe}: \mathrm{Va}}^{\kappa} \\
& +y_{\mathrm{Fe}}^{(1)} y_{\mathrm{Al}}^{(2)} y_{\mathrm{Fe}}^{(2)} y_{\mathrm{C}}^{(3)} L_{\mathrm{Fe}: \mathrm{Al}, \mathrm{Fe}: \mathrm{C}}^{\kappa}+y_{\mathrm{Fe}}^{(1)} y_{\mathrm{Al}}^{(2)} y_{\mathrm{Fe}}^{(2)} y_{\mathrm{Va}}^{(3)} L_{\mathrm{Fe}: \mathrm{Al}, \mathrm{Fe}: \mathrm{Va}}^{\kappa} \\
& +y_{\mathrm{Al}}^{(1)} y_{\mathrm{Al}}^{(2)} y_{\mathrm{C}}^{(3)} y_{\mathrm{Va}}^{(3)} L_{\mathrm{Al}: \mathrm{Al}: \mathrm{C}, \mathrm{Va}}^{\kappa}+y_{\mathrm{Al}}^{(1)} y_{\mathrm{Fe}}^{(2)} y_{\mathrm{C}}^{(3)} y_{\mathrm{Va}}^{(3)} L_{\mathrm{Al}: \mathrm{Fe}: \mathrm{C}, \mathrm{Va}}^{\kappa} \\
& +y_{\mathrm{Fe}}^{(1)} y_{\mathrm{Al}}^{(2)} y_{\mathrm{C}}^{(3)} y_{\mathrm{Va}}^{(3)} L_{\mathrm{Fe}: \mathrm{Al}: \mathrm{C}, \mathrm{Va}}^{\kappa}+y_{\mathrm{Fe}}^{(1)} y_{\mathrm{Fe}}^{(2)} y_{\mathrm{C}}^{(3)} y_{\mathrm{Va}}^{(3)} L_{\mathrm{Fe}: \mathrm{Fe}: \mathrm{C}, \mathrm{Va}}^{\kappa} \cdots \ldots . .(9)
\end{aligned}
$$

\subsubsection{Stoichiometric Compounds}

Phases with zero homogeneity range, i.e., $\mathrm{FeAl}_{2}, \mathrm{Fe}_{2} \mathrm{Al}_{5}$, and $\mathrm{Al}_{4} \mathrm{C}_{3}$, were treated as being stoichiometric compounds. For example, the Gibbs energy of the $\mathrm{Fe}_{2} \mathrm{Al}_{5}$ phase was expressed using the following equation, and by adopting the stable structure for the given elements as the thermodynamic standard state.

$$
G_{\mathrm{Al}: \mathrm{Fe}}^{\mathrm{Fe}_{2} \mathrm{Al}_{5}}-0.286^{\circ} G_{\mathrm{Fe}}^{\mathrm{bcc}}-0.714^{\circ} G_{\mathrm{Al}}^{\mathrm{fcc}}=a+b T+c T \ln T+d T^{2}
$$

The $\mathrm{Al}_{0.6275} \mathrm{Fe}_{0.1375}(\mathrm{Al}, \mathrm{Va})_{0.235}$ type of thermodynamic model was applied to the $\mathrm{Fe}_{4} \mathrm{Al}_{13}$ phase to elucidate its small homogeneity range.

\subsubsection{Contribution of Magnetic Transitions to the Gibbs Energy}

The contribution to the Gibbs free energy due to any magnetic ordering was added to the non-magnetic part of 
the free energy as follows.

$$
G^{\varphi}=G_{\mathrm{m}}^{\varphi}+G_{\mathrm{mag}}^{\varphi}
$$

The magnetic Gibbs energy, $G_{\mathrm{mag}}^{\varphi}$, is given by the following expression. ${ }^{8,9)}$

$$
G_{\mathrm{mag}}^{\varphi}=R T \cdot f(\tau) \ln (\beta+1)
$$

where

$$
\begin{array}{r}
f(\tau)=1-\frac{1}{A}\left\{\frac{79 \tau^{-1}}{140 p}+\frac{474}{497}\left(\frac{1}{p}-1\right)\left(\frac{\tau^{3}}{6}+\frac{\tau^{9}}{135}+\frac{\tau^{15}}{600}\right)\right\}, \\
\text { for } \tau<1 \ldots \ldots \ldots \ldots \ldots \ldots \ldots \ldots \ldots \ldots \ldots \ldots \ldots \ldots \ldots \ldots \ldots \ldots \ldots
\end{array}
$$

and

$$
f(\tau)=-\frac{1}{A}\left(\frac{\tau^{-5}}{10}+\frac{\tau^{-15}}{315}+\frac{\tau^{-25}}{1500}\right), \text { for } \tau \geq 1
$$

and

$$
A=\frac{518}{1125}+\frac{11692}{15975}\left(\frac{1}{p}-1\right)
$$

The variable $\tau$ was defined as $T / T c$, where $T c$ is the Curie temperature, and $\beta$ is the mean atomic moment expressed in Bohr magnetons, $\mu_{\mathrm{B}}$. The parameter $p$ depends on the crystal structure, with $p=0.4$ for the bcc phase, and $p=0.28$ for the fcc phase.

Although the ternary carbide $\kappa$ is known to be a ferromagnetic phase, the extra Gibbs energy originating in the magnetic transition was included in the formation energy derived by the ab initio calculations, as described in the following section.

\section{Results and Discussion}

\subsection{Calculation of the Thermodynamic Properties of the $\kappa$ Phase}

Prior to the calculation of thermodynamic properties for the $\kappa$ phase, a comparison of the calculated formation energies with the experimental values was attempted for some typical carbides observed in steels to clarify the validity of the FLAPW method. Table 2 shows the formation energy, $\Delta E_{\text {form }}^{\varphi}$, defined by averaging the total energy of the constituent elements with chemical composition up to the segregation limit, as follows.

$$
\Delta E_{\mathrm{form}}^{\varphi}=E_{\mathrm{tot}}^{\varphi}-x_{\mathrm{M}}^{\varphi} E_{\mathrm{tot}}^{\mathrm{M}}-\left(1-x_{\mathrm{M}}^{\varphi}\right) E_{\mathrm{tot}}^{\mathrm{C}}
$$

where $\varphi$ denotes the type of carbide, and $\mathrm{M}$ and $\mathrm{C}$ represent a metallic element and graphite, respectively. For example, the formation energy of $\mathrm{Fe}_{3} \mathrm{C}$ in the paramagnetic state was calculated to be $17.9 \mathrm{~kJ} / \mathrm{mol}$, while the formation energy of $\mathrm{Fe}_{3} \mathrm{C}$ on considering the spin polarization was $8.1 \mathrm{~kJ} / \mathrm{mol}$. This result shows the effect of the ferromagnetism of the $\mathrm{Fe}_{3} \mathrm{C}$ phase in the lower temperature region. Furthermore, because the formation energy from bcc Fe and graphite is positive, the $\mathrm{Fe}_{3} \mathrm{C}$ structure is less stable than graphite at absolute zero. The calculated formation energies for the

\begin{tabular}{|c|c|c|c|c|c|}
\hline Carbides & Space group & $\begin{array}{c}\text { Calculated lattice } \\
\text { parameter } \\
(\mathrm{nm})\end{array}$ & $\begin{array}{l}\text { Observed lattice } \\
\text { parameter } \\
(\mathrm{nm})\end{array}$ & $\begin{array}{l}\text { Calculated } \\
\text { formation } \\
\text { enthalpy in the } \\
\text { ground state } \\
(\mathrm{kJ} / \mathrm{mol})\end{array}$ & $\begin{array}{c}\text { Observed } \\
\text { formation enthalpy } \\
\text { at } 25^{\circ} \mathrm{C}^{10)} \\
(\mathrm{kJ} / \mathrm{mol})\end{array}$ \\
\hline $\begin{array}{c}\mathrm{Fe}_{3} \mathrm{C} \\
\text { (paramagnetic) }\end{array}$ & Pnma & $\begin{array}{l}a=0.4871 \\
b=0.6455 \\
c=0.4330\end{array}$ & - & +17.9 & - \\
\hline$\underset{\text { (ferromagnetic) }}{\mathrm{Fe}_{3} \mathrm{C}}$ & Pnma & $\begin{array}{l}a=0.5018 \\
b=0.6650 \\
c=0.4460\end{array}$ & $\begin{array}{c}a=0.5078 \\
b=0.67297 \\
c=0.45144 \\
\left(\text { Meinhard tet.a. }{ }^{31} \text { ) }\right.\end{array}$ & +8.1 & +6.3 \\
\hline $\mathrm{Cr}_{7} \mathrm{C}_{3}$ & Pnma & $\begin{array}{l}a=0.4373 \\
b=0.6772 \\
c=1.1730\end{array}$ & $\begin{array}{c}\mathrm{a}=0.4526 \\
\mathrm{~b}=0.7010 \\
\mathrm{c}=1.2142 \\
\text { (Rouault et al. }{ }^{32} \text { ) }\end{array}$ & -19.8 & -22.8 \\
\hline $\mathrm{Cr}_{23} \mathrm{C}_{6}$ & Fm-3m & $\mathrm{a}=1.0475$ & $\begin{array}{c}\mathrm{a}=1.06595 \\
\left(\text { Yakel }^{\mid 33}\right)\end{array}$ & -21.8 & -19.7 \\
\hline
\end{tabular}
$\mathrm{Cr}_{7} \mathrm{C}_{3}$ and $\mathrm{Cr}_{23} \mathrm{C}_{6}$ phases show a reasonable agreement with the thermodynamic data reported in the literature. ${ }^{10)}$ From consideration of the data shown in Table 2, the thermody-
Table 2. Comparison of the calculated formation energies

\begin{tabular}{|c|c|c|c|c|c|}
\hline Structure & $\begin{array}{c}\text { Strukturbericht } \\
\text { symbol }\end{array}$ & magnetism & $\begin{array}{c}\text { Calculated } \\
\text { lattice } \\
\text { parameter } \\
(\mathrm{nm})\end{array}$ & $\begin{array}{c}\text { Observed } \\
\text { lattice } \\
\text { parameter } \\
(\mathrm{nm})\end{array}$ & $\begin{array}{c}\text { Calculated } \\
\text { formation } \\
\text { enthalpy in the } \\
\text { ground state } \\
\text { ( } \mathrm{kJ} / \mathrm{mol} \text { of } \\
\text { compound) }\end{array}$ \\
\hline \multirow{2}{*}{$\mathrm{Fe}_{3} \mathrm{AlC}$} & \multirow{2}{*}{$\mathrm{E} 2{ }_{1}$} & paramagnetic & 0.3677 & - & -128.5 \\
\hline & & ferromagnetic & 0.3677 & $\begin{array}{l}0.3781 \\
\text { (Palatnik } \\
\text { et al. }^{34} \text { ) }\end{array}$ & -139.5 \\
\hline $\mathrm{Al}_{3} \mathrm{FeC}$ & $\mathrm{E} 2{ }_{1}$ & paramagnetic & 0.3890 & - & +190.5 \\
\hline $\mathrm{Fe}_{3} \mathrm{Al}$ & $\mathrm{Ll}_{2}$ & paramagnetic & 0.3502 & - & -35.2 \\
\hline $\mathrm{FeAl}_{3}$ & $\mathrm{~L}_{2}$ & paramagnetic & 0.3734 & - & -67.6 \\
\hline $\mathrm{Fe}_{4} \mathrm{C}$ & - & paramagnetic & 0.3645 & - & +88.4 \\
\hline $\mathrm{Al}_{4} \mathrm{C}$ & - & paramagnetic & 0.4057 & - & +160.5 \\
\hline
\end{tabular}
with the experimental values for some typical steel carbides.

Table 3. Calculated thermodynamic parameters required by the $(\mathrm{Fe}, \mathrm{Al})_{3}(\mathrm{Fe}, \mathrm{Al})_{1}(\mathrm{C}, \mathrm{Va})_{1}$-type three-sublattice model.

namic properties for metallic carbides evaluated by the first principle calculations can be applied to the general procedures used in the CALPHAD method.

Then, the thermodynamic parameters required by the model in the $(\mathrm{Fe}, \mathrm{Al})_{3}(\mathrm{Fe}, \mathrm{Al})_{1}(\mathrm{C}, \mathrm{Va})_{1}$ form were evaluated using first principle calculations, and the results are listed in Table 3. The calculated values denote the formation enthalpies based on the stable structure of the pure element in the ground state. Besides these cohesive energies for the stoichiometric components, the interactions between atoms on the same sublattice were defined in the same way as for the thermodynamic parameters, and these interaction parameters, as well as the entropy term of the formation energy, were estimated using the experimental phase boundaries.

The ferromagnetic state of the $\kappa$ phase was calculated to be almost $10 \mathrm{~kJ} / \mathrm{mol}$ more stable than its paramagnetic state, and the magnetic moment of the phase was calculated 
to be $3.05 \mu_{\mathrm{B}}$. Fujimura and Ino $^{11)}$ investigated the Fe-8mass\%Al-2mass\%C alloy using Mössbauer spectroscopy. They homogenized the melt-quenched alloy at temperatures above $T=400^{\circ} \mathrm{C}$, and confirmed an $(\alpha+\kappa)$ two-phase structure. The chemical composition of the $\kappa$ phase was deduced to be $\mathrm{Fe}_{3} \mathrm{Al}_{1} \mathrm{C}_{1}$ from the observed lattice constants, applying the relationship between the lattice parameters and composition from Choo and Han. ${ }^{12)}$ According to the Mössbauer spectroscopy data, the $\kappa$ phase was paramagnetic in stoichiometric $\mathrm{Fe}_{3} \mathrm{Al}_{1} \mathrm{C}_{1}$, which contrasts with the ferromagnetic behaviour of non-stoichiometric $\mathrm{Fe}_{3} \mathrm{Al}_{1} \mathrm{C}_{0.64}$. However, pronounced non-stoichiometry is well known for the $\kappa$ phase in the $\mathrm{Fe}-\mathrm{Al}-\mathrm{C}$ system, and in reality, the calculated equilibrium composition of the specimen at $T=400^{\circ} \mathrm{C}$ was $\mathrm{Fe}_{3.51} \mathrm{Al}_{0.83} \mathrm{C}_{0.66}$, based on the phase diagram calculations, as shown in a later section. On consideration of these results, the magnetism of the $\kappa$ phase should be examined in more detail from both theoretical and experimental points of view.

\subsection{Electronic Structure and Phase Stability of the $\boldsymbol{\kappa}$ Phase}

As shown in Fig. 1, a crystallographic similarity exists between the Perovskite carbide $\kappa$ and the $\mathrm{Fe}_{3} \mathrm{Al}-\mathrm{L1}_{2}$ structure, i.e., a $\mathrm{C}$ atom is placed in the centre of an octahedron composed of six Fe atoms occupying the face-centred positions in the $\mathrm{L}_{2}$ structure. The actual calculated equilibrium lattice constant of the $\mathrm{Fe}_{3} \mathrm{Al}-\mathrm{L1}_{2}$ structure was $0.3502 \mathrm{~nm}$, while that of the $\kappa$ phase was $0.3677 \mathrm{~nm}$, which correspond well with the experimental results of Palm and Inden. ${ }^{13)}$ This fact implies that occupation by the $\mathrm{C}$ atoms in the octahedral interstitial sites causes an expansion of the $\mathrm{L}_{2}$ lattice. Since the calculated enthalpy of formation of the $\kappa$ phase $(-27.9 \mathrm{~kJ} / \mathrm{mol}$ of atoms $)$ is much lower than that of the $\mathrm{Fe}_{3} \mathrm{Al}-\mathrm{L}_{2}$ structure $(-8.8 \mathrm{~kJ} / \mathrm{mol}$ of atoms $)$, it is concluded that the interstitial $\mathrm{C}$ atoms enhance the stability of the $\mathrm{L}_{2}$ structure. Thus, the role of the $\mathrm{C}$ atoms will be discussed in the context of their electronic structure.

Figures 2 and $\mathbf{3}$ show the total density of states (total DOS) and the angular-momentum-resolved density of state for each element (p-DOS) for the $\mathrm{Fe}_{3} \mathrm{AlC}-\mathrm{E} 2_{1}(\kappa)$ and $\mathrm{Fe}_{3} \mathrm{Al}-\mathrm{L} 1_{2}$ structures, respectively. The term $\mathrm{E}_{\mathrm{f}}$ denotes the Fermi energy, and no electrons occupy electronic states above this energy level. In both structures, the DOS mainly consist of the contribution from the $\mathrm{Fe} d$-electrons. However, while observing these diagrams, we noticed a marked difference between these two structures, in that the Fermi level is located near the peak of the total DOS for the $\mathrm{Fe}_{3} \mathrm{Al}-\mathrm{L}_{2}$ structure, but decreases in a region with a very low DOS in the $\mathrm{Fe}_{3} \mathrm{AlC}-\mathrm{E} 2{ }_{1}$ structure. This fact indicates that, from an energetic point of view, the stable E2 structure of the $\kappa$ phase is highly preferred, compared with the $\mathrm{Fe}_{3} \mathrm{Al}-\mathrm{L}_{2}$ structure.

Figures 4(a) and 4(b) show the calculated electron charge density plots of the $\mathrm{Fe}_{3} \mathrm{AlC}-\mathrm{E} 2_{1}(\kappa)$ and $\mathrm{Fe}_{3} \mathrm{Al}-\mathrm{Ll}_{2}$ structures in the $(001 / 2)$ plane, where the contour lines correspond to an electron density of $100 \mathrm{e} / \mathrm{nm}^{3}$. The Fe atoms can be seen in the middle of the horizontal and vertical axes, while the $\mathrm{C}$ atoms are located in the centre of the Fig. 4(a). From these contour plots, it can be seen that bonding between the $\mathrm{Fe}$ and $\mathrm{C}$ atoms occurs in the
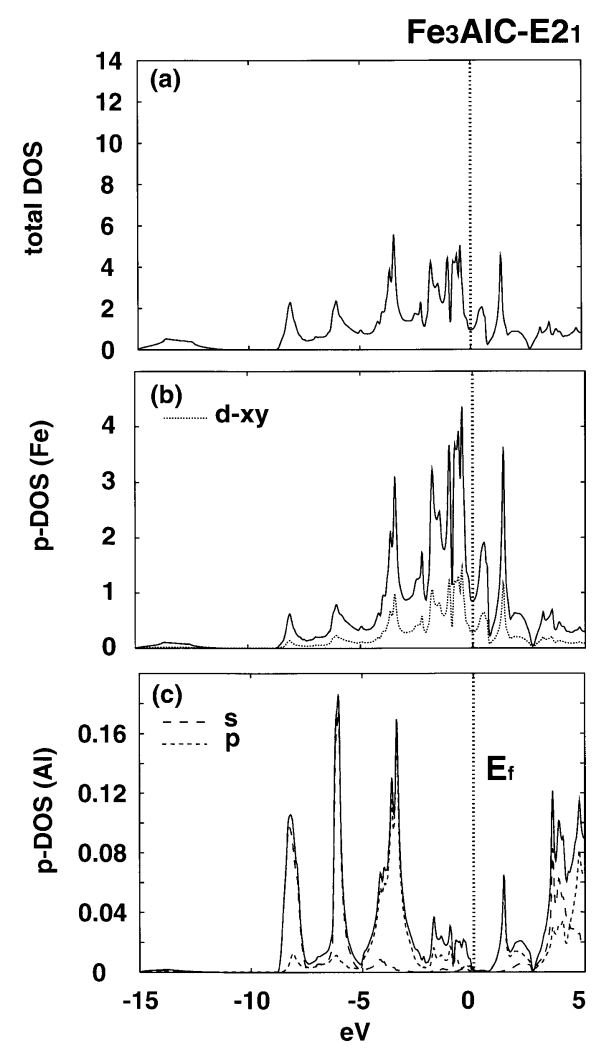

Fig. 2. (a) Total density of states, and angular-momentum-resolved density of state for: (b) $\mathrm{Fe}$ and (c) Al for the $\mathrm{Fe}_{3} \mathrm{AlC}-\mathrm{E} 2_{1}(\kappa)$ structure.
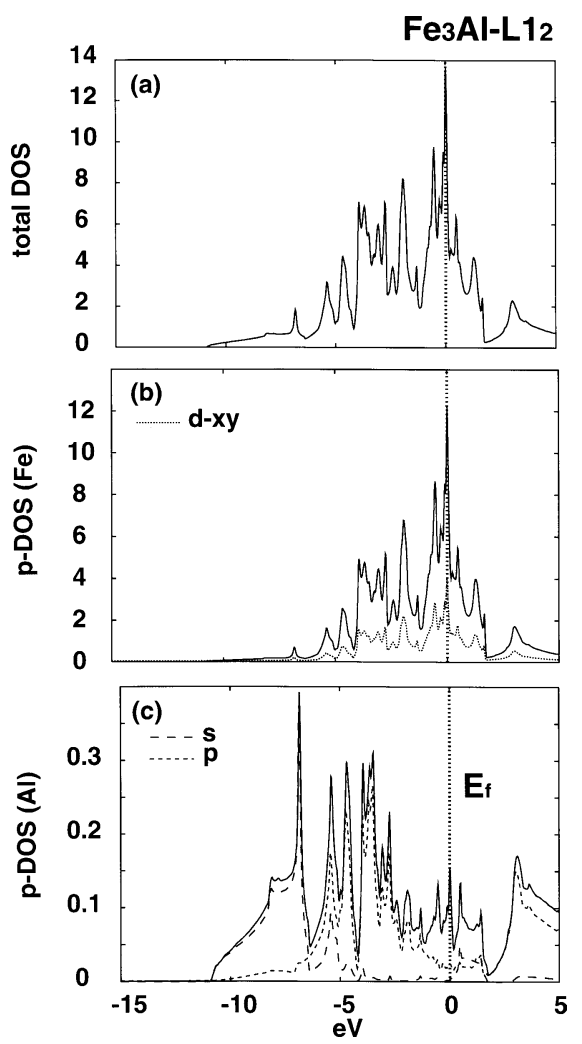

Fig. 3. (a) Total density of states, and angular-momentum-resolved density of state for: (b) $\mathrm{Fe}$ and (c) Al for the $\mathrm{Fe}_{3} \mathrm{Al}-\mathrm{Ll}_{2}$ structure.

$\mathrm{Fe}_{3} \mathrm{AlC}-\mathrm{E} 2{ }_{1}$ structure, since a finite charge density between these atoms can be observed. This interaction between the atoms enhances the energetic stability of the $\mathrm{Fe}_{3} \mathrm{AlC}-\mathrm{E} 2_{1}$ 
(a) Fe3AIC-E21

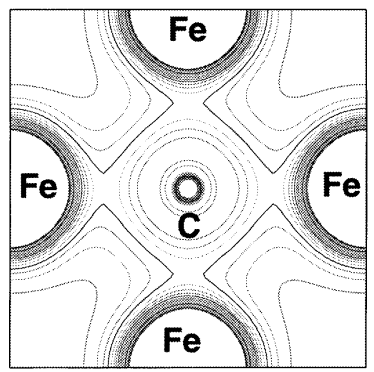

(b) Fe3AI-L12

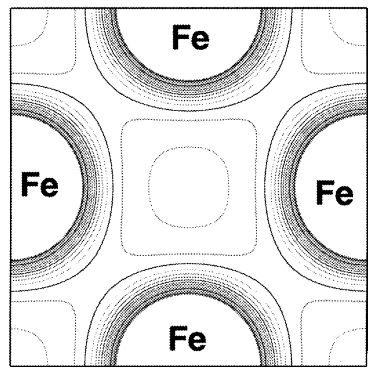

Fig. 4. Calculated electron charge density plots of: (a) the $\mathrm{Fe}_{3} \mathrm{AlC}-\mathrm{E} 2_{1}(\kappa)$ and (b) the $\mathrm{Fe}_{3} \mathrm{Al}-\mathrm{L} 1_{2}$ structures in the (lo 0 1/2) plane.

structure.

\subsection{Thermodynamic Analysis of the Phase Diagrams}

This section provides a brief outline of the thermodynamic analysis for the three binary systems and the ternary system. The descriptions of the lattice stability parameters for each pure element were obtained from the Scientific Group Thermodata Europe (SGTE) datafile, ${ }^{14)}$ and are shown in Table 4.

\subsubsection{Fe-C Binary System}

There are four phases in the stable $\mathrm{Fe}-\mathrm{C}$ binary system: liquid, an fcc disordered phase $(\gamma)$, a bcc disordered phase $(\beta)$, and graphite $(C)$. The thermodynamic description for the binary system as analysed by Gustafson ${ }^{15}$ ) was accepted in the present assessment. These parameters are listed in Table 5, and the calculated phase diagram is given in Fig. 5(a).

\subsubsection{Fe-Al Binary System}

The Fe-Al binary system is composed of: a liquid, an fcc disordered phase $(\gamma)$, a bcc disordered, and an ordered B2 phase $(\beta)$ of the four intermetallic compounds, $\mathrm{Fe}_{4} \mathrm{Al}_{5}$, $\mathrm{FeAl}_{2}, \mathrm{Fe}_{2} \mathrm{Al}_{5}$, and $\mathrm{Fe}_{4} \mathrm{Al}_{13}$. In our analysis, we accepted the results of Seiersten, ${ }^{16)}$ however, in his description of the $\beta$ phase, the ordering contribution to the total energy was added separately to the disordered term using a two-sublattice order-disorder model. Then, the parameters were converted so as to fit to the $(\mathrm{Fe}, \mathrm{Al})_{0.5}(\mathrm{Fe}, \mathrm{Al})_{0.5}$ framework formula. ${ }^{17)}$ The thermodynamic parameters used are listed in Table 5, and the calculated $\mathrm{Fe}-\mathrm{Al}$ binary system is shown in Fig. 5(b).

\subsubsection{Al-C Binary System}

Four phases: liquid, an fcc $\mathrm{Al}(\gamma)$, graphite $(\mathrm{C})$, and $\mathrm{Al}_{4} \mathrm{C}_{3}$, constitute the $\mathrm{Al}-\mathrm{C}$ binary system. The thermodynamic analysis of this binary system was performed in this study based on the results of Gröbner et al. ${ }^{18)}$ The $\mathrm{Al}_{4} \mathrm{C}_{3}$ phase was treated as a line compound, due to its zero homogeneity range. The parameters assessed are listed in Table 5, and the calculated phase diagram is shown in Fig. 5(c).

\subsubsection{Fe-Al-C Ternary System}

Morral $^{19)}$ investigated the phase equilibria in the $\mathrm{Fe}-\mathrm{Al}-\mathrm{C}$ ternary phase diagram based on metallographic and X-ray studies, and presented an isothermal section at $T=1000^{\circ} \mathrm{C}$, which was the first phase diagram constructed for this system. Unfortunately, the phase boundaries of the
Table 4. Lattice stability parameters for $\mathrm{Fe}, \mathrm{Al}$, and C.

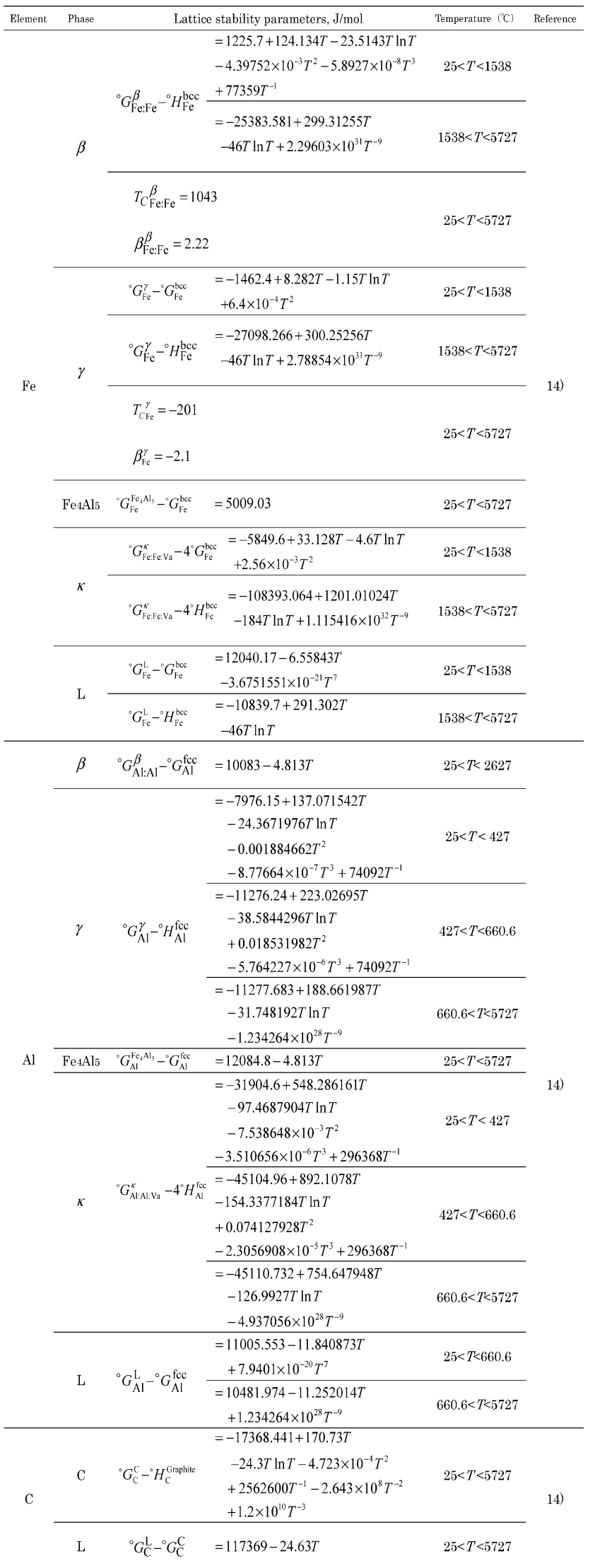

$\kappa$ phase remained uncertain, even after intensive work. Detailed investigations of the phase equilibria have also been reported by several other investigators. ${ }^{20-26)}$ Vyklicky and Tuma, ${ }^{21)}$ and Schenck and Kaiser ${ }^{22}$ have both claimed that $\mathrm{C}$ is soluble in the $\beta$ phase. An extensive work on the 
ISIJ International, Vol. 44 (2004), No. 10

Table 5. Optimized thermodynamic parameters for binary and ternary systems.

\begin{tabular}{|c|c|c|c|}
\hline System & Phase & Thermodynamic parameters, $\mathrm{J} / \mathrm{mol}$ & Reference \\
\hline \multirow{3}{*}{$\mathrm{Fe}-\mathrm{C}$} & $\beta$ & $\begin{array}{l}{ }^{\circ} G_{\mathrm{Fe}: \mathrm{Fe}: \mathrm{C}}^{\beta}-{ }^{\circ} G_{\mathrm{Fe}}^{\mathrm{bcc}}-3^{\circ} G_{\mathrm{C}}^{\mathrm{Gra}}=322050+75.667 T \\
{ }^{0} L_{\mathrm{Fe}: \mathrm{Fe}: \mathrm{C}, \mathrm{Va}}^{\beta}=-190 T \\
{ }^{0} T c_{\mathrm{Fe}: \mathrm{Fe}: \mathrm{C}}^{\beta}=1043 \\
{ }^{0} \beta_{\mathrm{Fe}: \mathrm{Fe}: \mathrm{C}}^{\beta}=2.22\end{array}$ & \\
\hline & $\gamma$ & 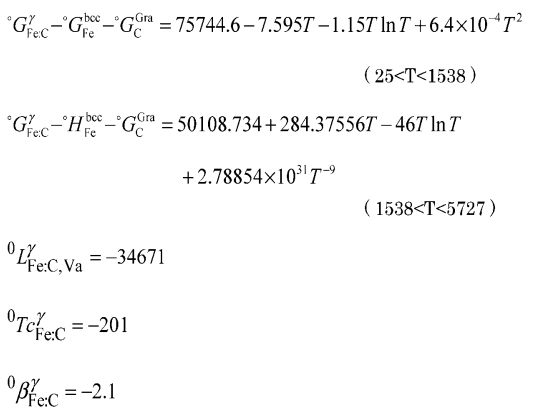 & 15) \\
\hline & $\mathrm{L}$ & $\begin{array}{l}{ }^{\circ} G_{\mathrm{Fe}: \mathrm{Fe}: \mathrm{C}}^{K}-4^{\circ} G_{\mathrm{Fe}}^{\mathrm{bcc}}-{ }^{\circ} G_{\mathrm{Al}}^{\mathrm{fcc}}=88400 \\
{ }^{0} L_{\mathrm{C}, \mathrm{Fe}}^{\mathrm{L}}=-124320+28.5 T \\
{ }^{1} L_{\mathrm{C}, \mathrm{Fe}}^{\mathrm{L}}=19300 \\
{ }^{2} L_{\mathrm{C}, \mathrm{Fe}}^{\mathrm{L}}=49260-19 T\end{array}$ & $\begin{array}{c}\text { present } \\
\text { work }\end{array}$ \\
\hline $\mathrm{Fe}-\mathrm{Al}$ & $\beta$ & 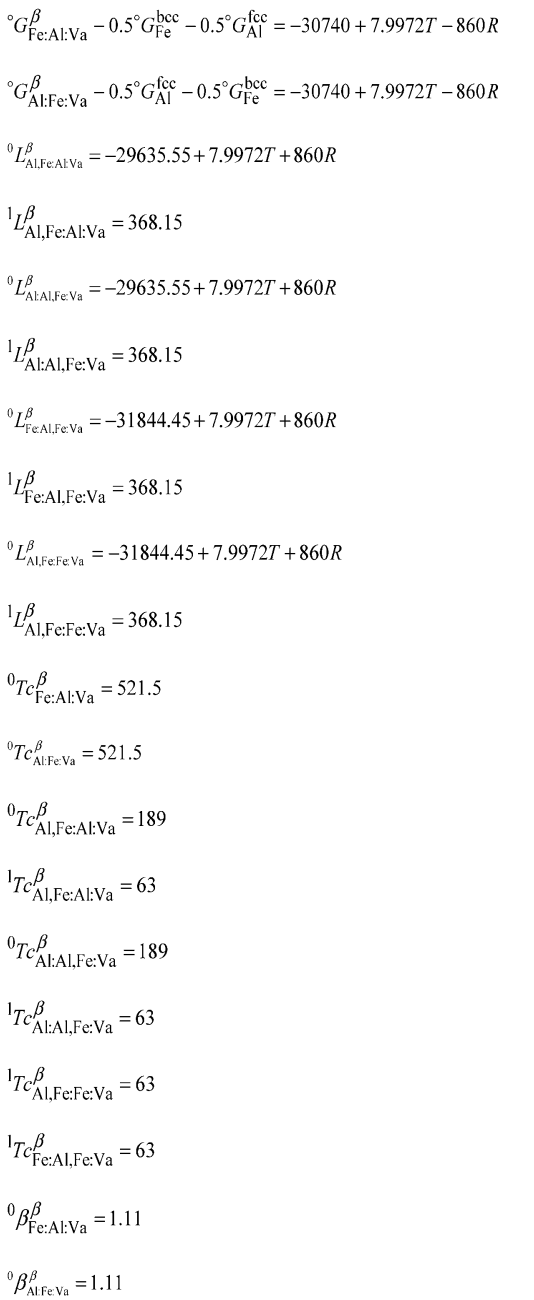 & . \\
\hline
\end{tabular}

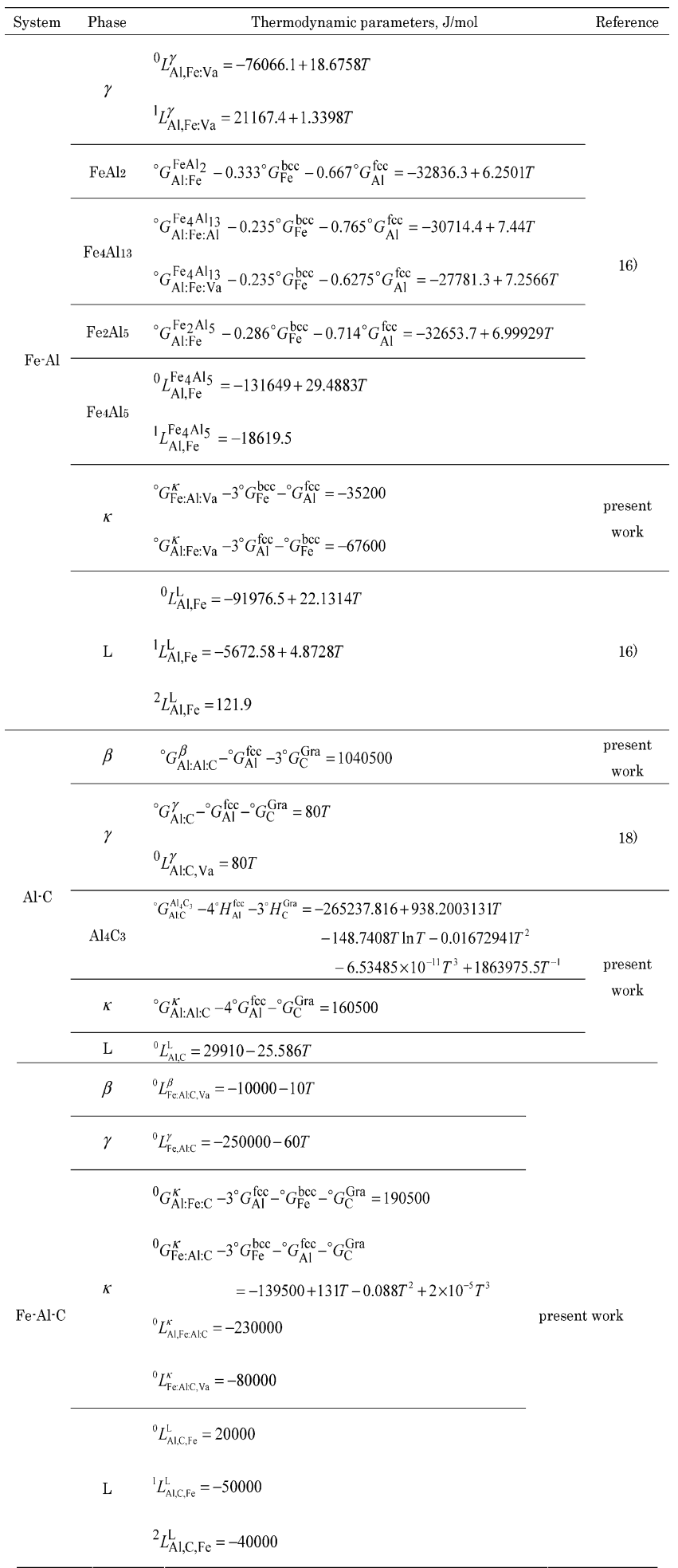


(a)

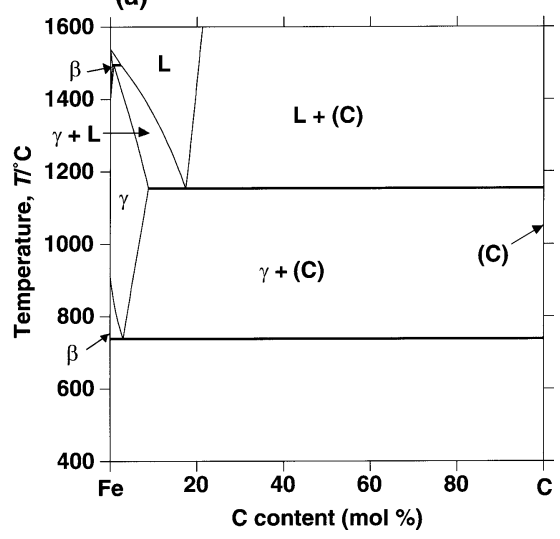

(b)

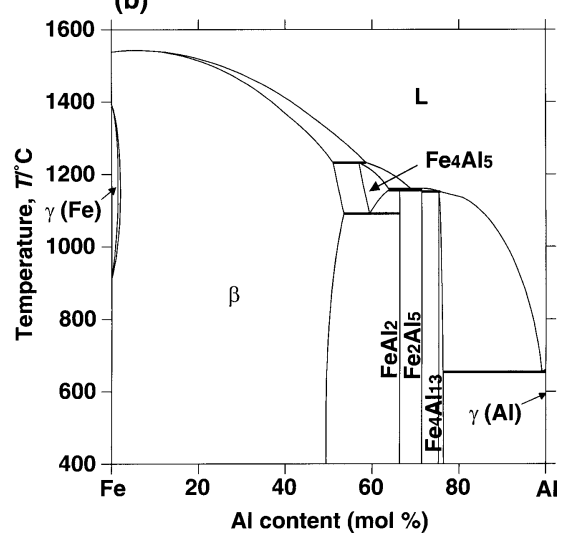

(c)

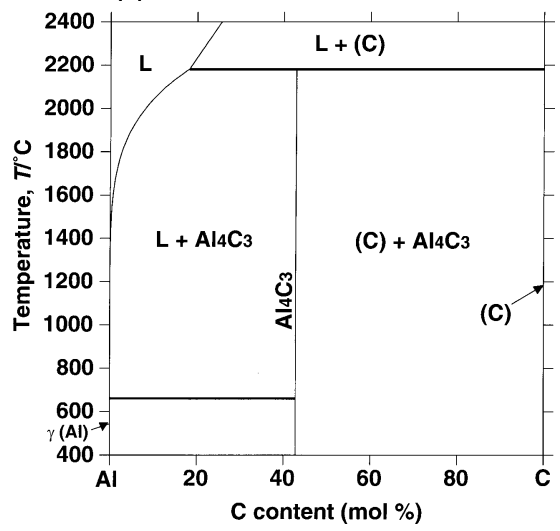

Fig. 5. The calculated binary phase diagrams for: (a) the $\mathrm{Fe}-\mathrm{C}$, (b) the $\mathrm{Fe}-\mathrm{Al}$, and (c) the $\mathrm{Al}-\mathrm{C}$ systems.

Fe-rich side of the system was carried out by Nishida. ${ }^{23)} \mathrm{He}$ prepared 24 alloys using electrolytic $\mathrm{Fe}$, pure $\mathrm{Al}$, and graphite melted in an argon gas atmosphere. These alloys were isothermally annealed between $T=1000$ and $T=1250^{\circ} \mathrm{C}$, and after quenching in iced brine, the isothermal sections of phase diagrams were investigated using hardness, microscopic, and X-ray examinations. Nishida obtained a good agreement with the findings of Morral ${ }^{19}$ ) for the isotherms at $T=1000^{\circ} \mathrm{C}$, but failed to determine the compositional range of the $\kappa$ phase. The liquidus surface and invariant reactions have been determined by Löhberg and Ueberschaer ${ }^{24,25)}$ and by Gorev and Gurinovich. ${ }^{26)}$

Raghavan $^{27,28)}$ reviewed the experimental data on this ternary system, and presented evaluated results for the liquidus projection on the Fe-rich side, along with reaction schemes and some isothermal sections. Kumar and $\operatorname{Raghavan}^{29)}$ performed a thermodynamic assessment, as- suming the $\kappa$ phase to have a fixed composition of $\mathrm{Fe}_{3} \mathrm{AlC}_{0.565}$. The most recent and reliable information on this ternary system is from the work of Palm and Inden. ${ }^{13)}$ They determined three isothermal section diagrams at $T=800,1000$, and $1200^{\circ} \mathrm{C}$ determined from electron microprobe analysis, as well as three vertical sections and the invariant reactions at the liquidus surface from high-temperature X-ray diffraction experiments. Palm and Inden pointed out the difficulties in determining the exact composition of the $\kappa$ phase arise from the precipitation of primary graphite, which commences at higher temperatures. This yields metastable phase equilibria in the expected $\kappa$ singlephase field, and therefore, single-phase $\kappa$ material cannot be obtained from the melt.

In the present study, the thermodynamic analysis was performed based mainly on the experimental phase diagrams of Palm and Inden. ${ }^{13)}$ No data on the thermodynamic properties of the ternary carbide $\kappa$ phase were available in the literature. Thus, the formation energy of the phase was determined using the results of the first principle calculations listed in Table 3. The optimized thermodynamic parameters are summarized in Table 5.

\subsection{Comparison of the Calculated Phase Equilibria with the Experimental Data}

The $\mathrm{Fe}-\mathrm{Al}-\mathrm{C}$ ternary phase diagrams were calculated using the thermodynamic parameters described in the previous section, and are shown in Fig. 6 for temperatures, $T=800,1000$, and $1200^{\circ} \mathrm{C}$. The enlarged portion of the isothermal section diagrams was compared with the experimental phase boundaries determined using X-ray diffraction and metallographic observation. ${ }^{13)}$ From EPMA measurements, they reported that the chemical composition of the $\kappa$ phase shifted remarkably from its stoichiometric composition, i.e., between $\mathrm{Fe}_{3.2} \mathrm{Al}_{0.8} \mathrm{C}_{0.71}$ and $\mathrm{Fe}_{2.8} \mathrm{Al}_{1.2} \mathrm{C}_{0.42}$. According to our calculations, the homogeneity range of this phase extends from $\mathrm{Fe}_{2.9} \mathrm{Al}_{1.1} \mathrm{C}_{0.7}$ to $\mathrm{Fe}_{2.8} \mathrm{Al}_{1.2} \mathrm{C}_{0.7}$ at $1200^{\circ} \mathrm{C}$. In the $(\gamma+\kappa)$ two-phase region shown in Figs. 6(b) and 6(c), the fcc disordered $\gamma$ phase coexists with the fcc-based ordered $\kappa$ phase. Considering the analogy with the $\left(\gamma+\gamma^{\prime}\right)$ microstructures in Ni base superalloys, this twophase structure may be beneficial for the heat resisting properties of these alloys, as reported by Kimura et al. ${ }^{4)}$ for the $\mathrm{Co}-\mathrm{Al}-\mathrm{C}$ system.

The solubility of $\mathrm{C}$ in the $\beta$ phase has been observed up to $1.5 \mathrm{~mol} \%{ }^{13)}$ However, this was not well reproduced in our calculations. The difference in the calculated $(\beta+\gamma+\kappa)$ three-phase region with the experimental findings originates in its lower solubility in our work. In the framework of the $(\mathrm{Fe}, \mathrm{Al})_{0.5}(\mathrm{Fe}, \mathrm{Al})_{0.5}(\mathrm{C}, \mathrm{Va})_{3}$-type sublattice model, one of the thermodynamic parameters particular to the ternary system are hypothetical formation energies, such as $\mathrm{Fe}_{0.5} \mathrm{Al}_{0.5} \mathrm{C}_{3}$, that are defined along the $\mathrm{C}=75 \mathrm{~mol} \%$ line in the composition triangle. However, according to the FLAPW method, the formation energy of the hypothetical structure was calculated to be $+213.6 \mathrm{~kJ} / \mathrm{mol}$, and thus the parameter is unlikely to increase the solubility of $\mathrm{C}$ in the $\beta$ phase. When $\mathrm{C}$ atoms occupy only the octahedral interstitial sites, the formation energy of $+176.7 \mathrm{~kJ} / \mathrm{mol}$ was obtained for the $\mathrm{Fe}_{0.5} \mathrm{Al}_{0.5} \mathrm{C}_{1.5}$ structure, and the contribution to the free energy from these parameters is quite small. The 

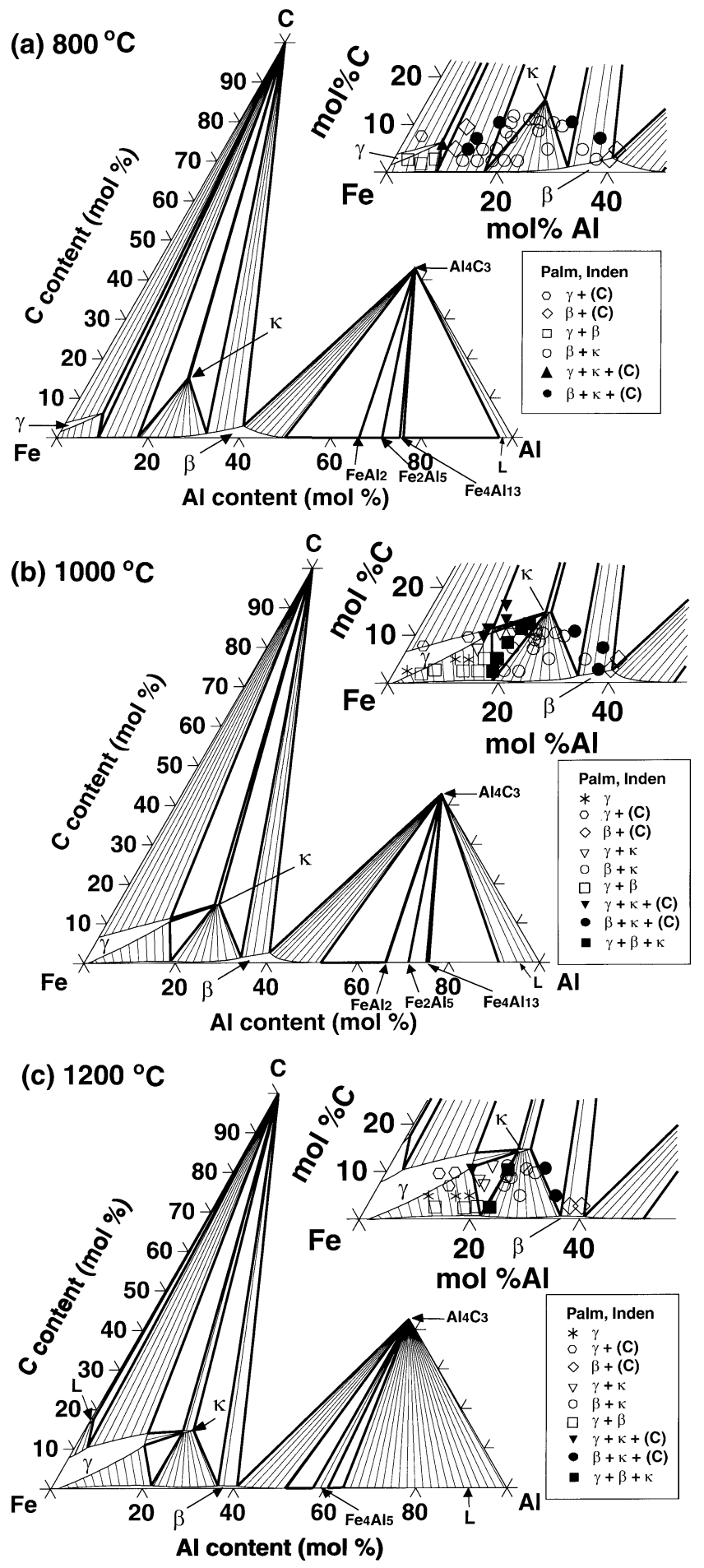

Fig. 6. Isothermal section diagram calculated at: (a) $800^{\circ} \mathrm{C}$, (b) $1000^{\circ} \mathrm{C}$, and (c) $1200^{\circ} \mathrm{C}$ with an enlarged portion on the Fe-rich side.

situation is similar in the calculation for the $\mathrm{Fe}_{0.5} \mathrm{Al}_{0.5} \mathrm{C}_{1.5}$ structure, in which $\mathrm{C}$ atoms occupy the tetrahedral interstitial sites. Therefore the free energy of the $\beta$ phase is mainly dependent on the parameters of the $\mathrm{Fe}-\mathrm{Al}$ binary system, as well as on the entropy of mixing with the $\mathrm{C}$ atoms and the vacancies. Since the contribution of the mixing entropy increases with increasing temperature, the concentration of dissolved $\mathrm{C}$ in the $\beta$ phase increases at $T=1200^{\circ} \mathrm{C}$, as shown in Fig. 6(c), and this leads to an improved correspondence with the experimental data. Considering this aspect, the thermodynamic description of the $\mathrm{Fe}-\mathrm{Al}$ binary (a) $5 \mathrm{~mol} \% \mathrm{C}$

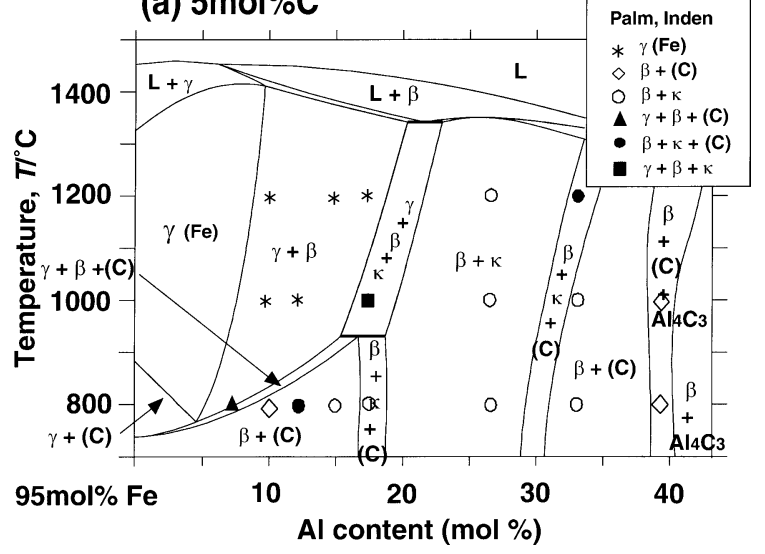

(b) $10.5 \mathrm{~mol} \% \mathrm{C}$

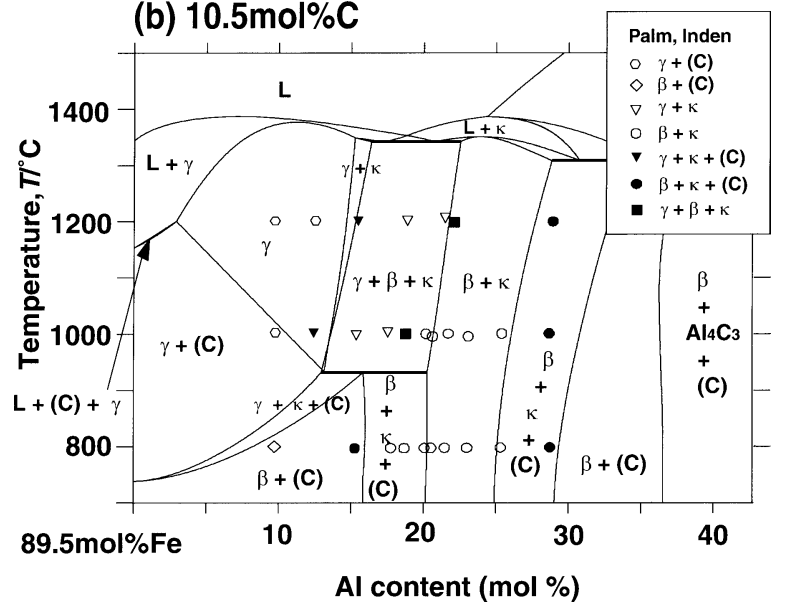

Fig. 7. Calculated vertical section diagrams at a constant $\mathrm{C}$ content of (a) 5 and (b) $10.5 \mathrm{~mol} \%$.

system may be modified to reproduce higher carbon solubility.

The calculated vertical section diagrams at constant $\mathrm{C}$ contents of 5 and $10.5 \mathrm{~mol} \%$ are shown in Fig. 7 . Compared to the experimental phase fields ${ }^{13)}$ denoted by several symbols, the correspondence with the entire phase diagram is acceptable, although the calculated $(\gamma+(\mathrm{C}))$ two-phase field and the $(\gamma+\kappa+(C))$ three-phase field are slightly shifted towards the Fe-rich side. A three-phase field exists in the vicinity of $\mathrm{Al}=15 \mathrm{~mol} \%$ in these vertical section diagrams. The B2-type structure, $\beta$, exhibits a high oxidation resistance, and is an important surface coating material for superalloys. However, the $\beta$ phase is generally quite brittle, and such alloys are usually unworkable at lower temperatures. Considerable effort has been directed towards improving the ductility of B2-type intermetallic compounds, and some groups have succeeded in fabricating ductile materials in the presence of the fcc $\gamma$ phase. Thus, the $(\gamma+\beta+\kappa)$ phase field may play a key role in seeking new types of high-temperature materials that have good oxidation resistance and strength. ${ }^{30)}$

The calculated liquidus projection on the Fe-rich side is shown in Fig. 8. The dashed lines represent the isotherms obtained at the temperatures indicated in Fig. 8. The invariant reactions are denoted by the filled circles. The following four phases are in equilibrium at these points

\footnotetext{
$\mathrm{U}_{1}: \mathrm{L}+\beta \Leftrightarrow \gamma+\kappa$ at $1342^{\circ} \mathrm{C}, 19.99 \mathrm{~mol} \% \mathrm{Al}$, and $8.94 \mathrm{~mol} \% \mathrm{C}$
} 


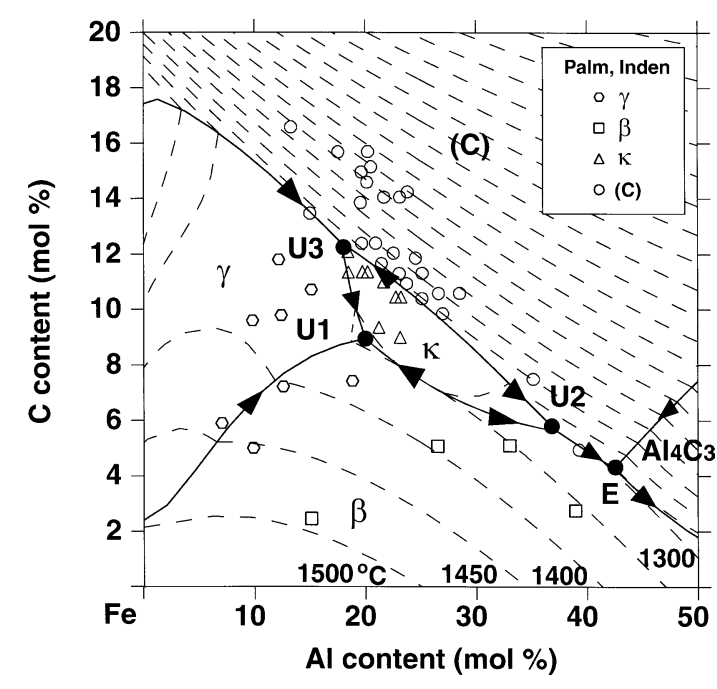

Fig. 8. Calculated liquidus projection on the Fe-rich side.

$$
\begin{aligned}
\mathrm{U}_{2}: & \mathrm{L}+\kappa \Leftrightarrow \beta+(\mathrm{C}) \text { at } 1308^{\circ} \mathrm{C}, 37.25 \mathrm{~mol} \% \mathrm{Al} \text {, and } \\
& 5.63 \mathrm{~mol} \% \mathrm{C} \\
\mathrm{U}_{3}: & \mathrm{L}+\kappa \Leftrightarrow \gamma+(\mathrm{C}) \text { at } 1365^{\circ} \mathrm{C}, 17.82 \mathrm{~mol} \% \mathrm{Al} \text {, and } \\
& 12.41 \mathrm{~mol} \% \mathrm{C} \text {. }
\end{aligned}
$$

and

$$
\begin{aligned}
\mathrm{E}: \mathrm{L} \Leftrightarrow \beta+(\mathrm{C})+\mathrm{Al}_{4} \mathrm{C}_{3} \text { at } 1297^{\circ} \mathrm{C}, 42.44 \mathrm{~mol} \% \mathrm{Al} \text {, and } \\
\\
\quad 4.24 \mathrm{~mol} \% \mathrm{C} .
\end{aligned}
$$

\section{Conclusions}

The phase equilibria in the $\mathrm{Fe}-\mathrm{Al}-\mathrm{C}$ ternary system were investigated by incorporating $a b$ initio energetic calculations into the CALPHAD approach, yielding the following results.

(1) The Gibbs free energy for the ternary Perovskite carbide, $\mathrm{Fe}_{3} \mathrm{AlC}(\kappa)$ was expressed by the $(\mathrm{Fe}, \mathrm{Al})_{3}(\mathrm{Fe}, \mathrm{Al})_{1}(\mathrm{C}, \mathrm{Va})_{1}$ type of sublattice model, and treating this phase as a continuous solution with a metastable $\mathrm{Fe}_{3} \mathrm{Al}-\mathrm{Ll}_{2}$ structure. Because of the lack of experimental information available, the formation enthalpy of this ternary carbide was evaluated using the Full Potential Linearized Augmented Plane Wave method. In addition to the cohesive energies in the ground state, the entropy term of the formation energy, as well as the atomic interaction energies were evaluated based on the experimental phase boundaries.

(2) According to our electronic structure analysis based on the density of states and charge density plots, the occupation of a $\mathrm{C}$ atom in the octahedral interstitial site in the $\mathrm{L1}_{2}$ structure results in the formation of bonds between the $\mathrm{Fe}$ and $\mathrm{C}$ atoms, and this interaction enhances the energetic stability of the $\mathrm{Fe}_{3} \mathrm{AlC}-\mathrm{E} 2_{1}$ structures.

(3) The phase diagram calculations show that the E2 1 phase in the $\mathrm{Fe}-\mathrm{Al}-\mathrm{C}$ system is in equilibrium with the fcc Fe, B2-type intermetallic compound, and the graphite phase. This finding is in good agreement with previous experimental results. The results obtained in the present study greatly encourage us that a combination of $a b$ initio energetic calculations with the CALPHAD method can be a useful tool in the construction of higher-order phase diagrams.

\section{Acknowledgements}

The authors gratefully acknowledge helpful discussions with Dr. Y. Kimura and Prof. Y Mishima at the Tokyo Institute of Technology. The authors also acknowledge the great effort expended by Dr. I. Ohnuma at Tohoku University in converting the thermodynamic parameters of the $\mathrm{Fe}-\mathrm{Al}$ system. The authors express their sincere thanks to Mr. H. Minooka at the Kyushu Institute of Technology for his assessment of the Al-C system. This work was partially supported by a Grant-in-aid for Scientific Research (No.14550720) from the Ministry of Education, Science, Sports and Culture of Japan.

\section{REFERENCES}

1) N. Saunders and A. P. Miodownik: Calphad (Calculation of Phase Diagrams): A Comprehensive Guide, Pergamon Materials Series, Elsevier Science Ltd., Oxford, (1998).

2) D. J. Singh: Planewaves, Pseudopotentials and the LAPW Method, Kluwer Academic Pub., Boston, (1994).

3) H. Ohtani and M. Hasebe: Bull. Iron Steel Inst. Jpn., 9 (2004), 223.

4) Y. Kimura, M. Takahashi, S. Miura, T. Suzuki and Y. Mishima: Intermetallics, 3 (1995), 413.

5) P. Blaha, K. Schwarz, G. K. H. Madsen, D. Kvasnicka and J. Luiz: WIEN2k, An Augmented Plane Wave + Local Orbitals Program for Calculating Crystal Properties, Karlheinz Schwarz, Tech. Universität Wien, Austria, (2001).

6) J. P. Perdew, K. Burke and Y. Wang: Phys. Rev., 54B (1996), 16533.

7) M. Hillert and L.-I. Staffansson: Acta Chem. Scand., 24 (1970), 3618.

8) G. Inden: Report on the Project Meeting Calphad, V (1976), June, 1.

9) M. Hillert and M. Jarl: Calphad, 2 (1978), 227.

10) R. Hultgren, P. D. Desai, D. T. Hawkins, M. Gleiser and K. K. Kelley: Selected Values of the Thermodynamic Properties of Binary Alloys, ASM, Metals Park, OH, (1973).

11) H. Fujimura and H. Ino: J. Jpn. Inst. Met., 59 (1995), 686.

12) W. K. Choo and K. H. Han: Metall. Trans., 16A (1985), 5.

13) M. Palm and G. Inden: Intermetallics, 3 (1995), 443.

14) A. T. Dinsdale: Calphad, 15 (1991), 317.

15) P. Gustafson: Scand. J. Metall., 14 (1985), 259.

16) M. Seiersten: Unpublished work (1989). The assessed parameters are recorded in the SGTE (Scientific Group Thermodata Europe) Solution Database of Jan. 1994, ed. by B. Sundman, Royal Institute of Technology, S-10044 Stockholm, Sweden.

17) I. Ohnuma, R. Kainuma and K. Ishida: CALPHAD and Alloy Thermodynamics, ed. by P. E. A. Turchi, A. Gonis and R. D. Shull, TMS, Warrendale, PA, (2002), 61.

18) J. Gröbner, H. L. Lukas and F. Aldinger: COST507: Thermodynamic Database for Light Metal Alloys, Vol. 2. ed. by I. Ansara, A. T. Dinsdale and M. H. Rand, Office for Official Publications of the European Communities, Luxembourg, (1998), 18.

19) F. R. Morral: J. Iron Steel Inst., 130 (1934), 419.

20) K. Löhberg and W. sSchmidt: Arch. Eisenhüttenwes., 11 (1938), 607.

21) M. Vyklicky and H. Tuma: Hutni. Listy, 14 (1959), 118.

22) H. Schenck and H. Kaiser: Arch Eisenhüttenwes., 31 (1960), 227.

23) K. Nishida: Tech. Rep. Hokkaido Univ., 48 (1968), 71.

24) K. Löhberg and A. Ueberschaer: Giessereiforschung, 21 (1969), 163.

25) K. Löhberg and A. Ueberschaer: Giessereiforschung, 21 (1969), 171.

26) K. V. Gorev and V. I. Gurinovich: Stable and Metastable Phase Equilibria in Metallic Systems, Nauka, Moscow, (1985), 119.

27) V. Raghavan: Phase Diagrams of Ternary Iron Alloys, Part 1, ASM, Metals Park, OH, (1987), 89.

28) V. Raghavan: J. Phase Equilibria, 14 (1993), 615.

29) K. C. Hari Kumar and V. Raghavan: J. Phase Equilibria, 12 (1991), 275 .

30) R. Kainuma, S. Imano, H. Ohtani and K. Ishida: Intermetallics, 4 (1996), 37.

31) D. Meinhardt and O. Krisement: Arch. Eisenhüttenwes., 33 (1962), 493.

32) M. A. Rouault, P. Herpin and M. R. Fruchart: Ann. Chim. Sci. Mater, 5 (1970), 461.

33) H. L. Yakel: Acta Crystallogr., 43B (1987), 230.

34) L. S. Palatnik, I. A. Tananko and Yu. G. Bobro: Kristallografiya, 9 (1964), No. 2, 163 
ISIJ International, Vol. 44 (2004), No. 10 